\title{
Mapping of the Results of the Second Round of Tunisia's 2019 Presidential Elections
}

\author{
Mongi Belarem ${ }^{1,2 *}$ \\ ${ }^{I}$ Syfacte Research Laboratory, Department of Geography, Faculty of Humanities and Arts, University of Sfax, \\ ATCIG, Sfax, Tunisia \\ ${ }^{2}$ Department of Geography and GIS, Faculty of Humanities and Arts, King Abdulaziz University, Jeddah, KSA \\ *Corresponding Author: Mongi Belarem, Syfacte Research Laboratory, Department of Geography, \\ Faculty of Humanities and Arts, University of Sfax, ATCIG, Sfax, Tunisia \& Department of Geography \\ and GIS, Faculty of Humanities and Arts, King Abdulaziz University, Jeddah, KSA
}

\begin{abstract}
Mapping is one of the tools for analyzing election data. It enables the visualization and analysis of different electoral variables.This paper aims to analyze the results of the second round of Tunisian's 2019 presidential elections. The results declared by the Independent Higher Authority of the Elections (IHAE) show that the candidate Kaïs Saïed won against the candidate Nabil Karoui. This victory was in all the constituencies, but with great inequalities between the different constituencies

The mapping and analysis of the results show large spatial inequalities between the different regions. The participation rate during these elections is relatively average. Valid and invalid votes show large variations between the northern and southern regions on the one hand, and between the coastal and the inland regions on the other.
\end{abstract}

Keywords: Mapping, spatial distribution, presidential elections, Tunisia

\section{INTRODUCTION}

During the first round of the 2019 Tunisian presidential elections, the two candidates K. Saïed and N. Karoui, passed in the second round, against 24 other candidates. K. Saïed passed with 620711 votes, that is to say $18.4 \%$ of all valid votes. N. Karoui obtained 525517 votes, that is $15.58 \%$ of all votes cast (Figure 9). During the 2nd round, the candidate K. Saïed is declared as president of the republic. He won with $72.71 \%$ (2777931 votes). The second candidate N. Karoui, had $27.29 \%$ of the votes, that is to say 1042894 votes (www.isie.tn).

The visualization of the results of the elections, through the maps, shows great spatial inequalities between the different constituencies. These inequalities concern the participation rates, the number of votes (declared, blank and null) and the votes and proportions obtained by each candidate.

To carry out this work we began by presenting the study area and the methodology followed. Then we mapped and analyzed the results through: the participation rate, the results obtained by each of the two candidates, the white and the null votes.

\section{STUdy AREA AND Methodology}

\subsection{The Study Area}

In this study, we only deal with results within the country (figure 1). "The Tunisian territory is made up of 27 constituencies. 24 governorates define constituencies. Each of the three governorates of Tunis, Nabeul and Sfax is subdivided into two constituencies" (Belarem M., 2020 and, 2019; Belarem M.2017; Dhieb M. and Belarem M., 2016). 


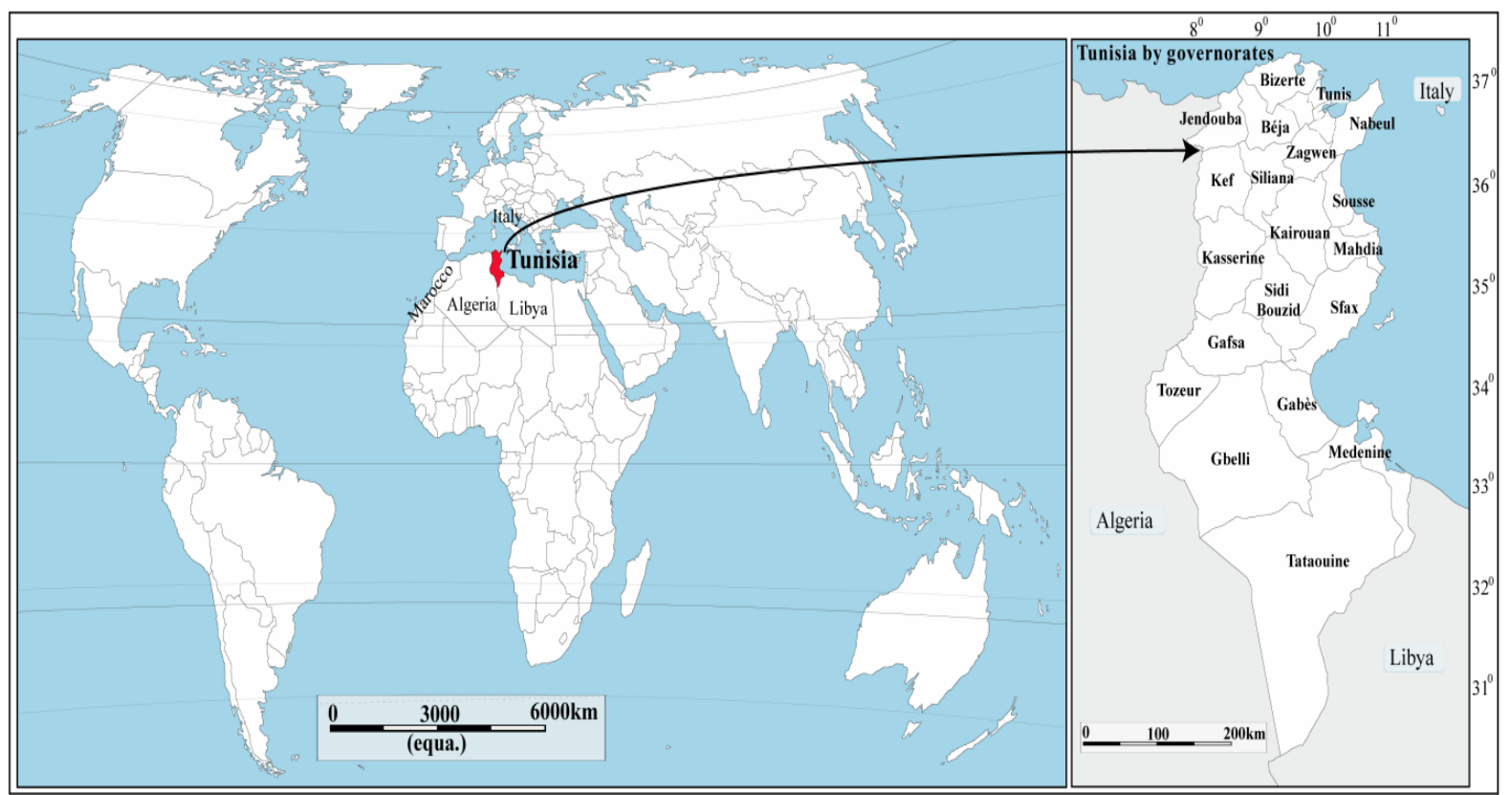

Figure1. Study area (Source: d-maps, modified by the author)

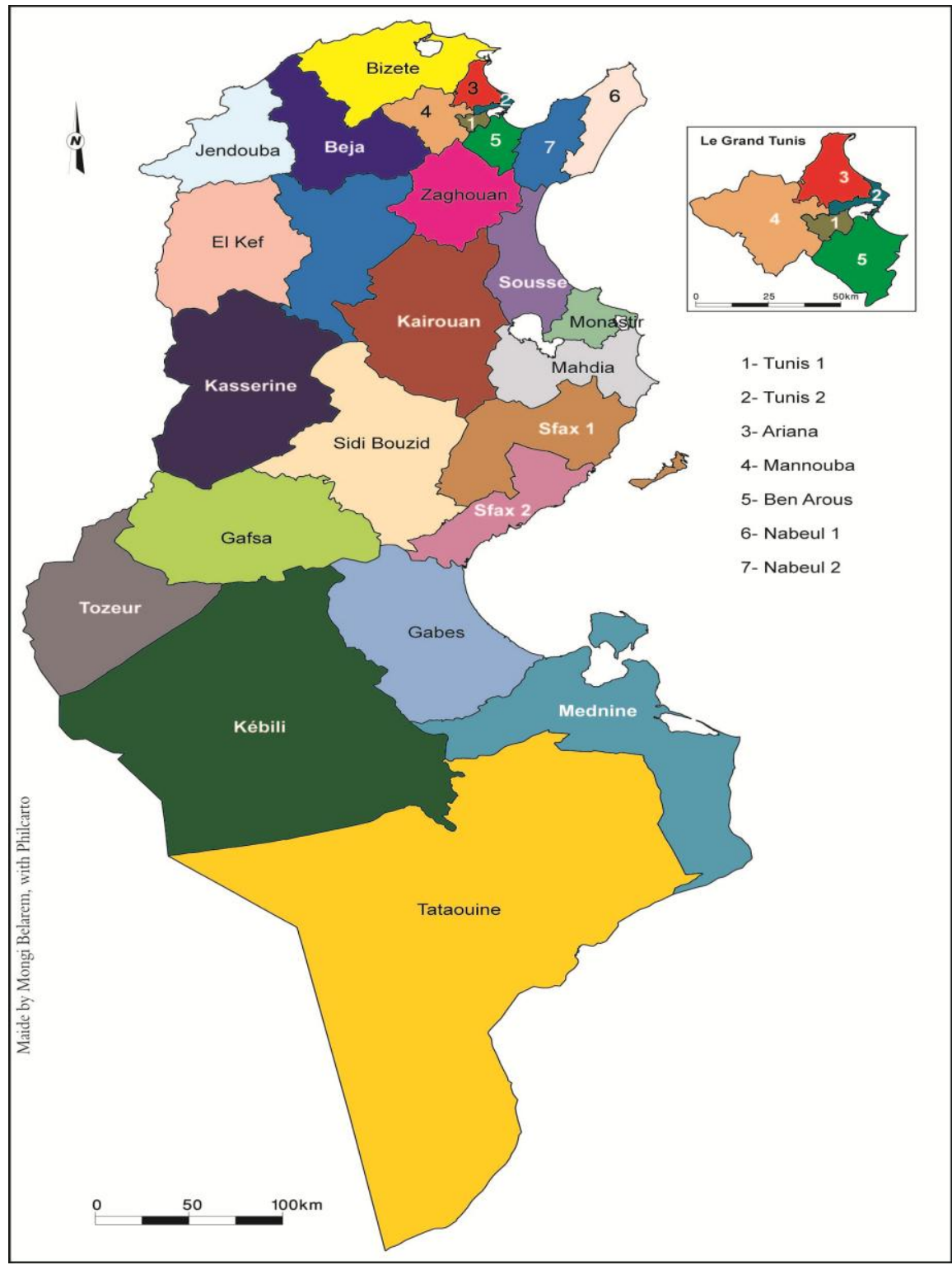

Figure2. Tunisian electoral constituencies in 2019. (Source: Belarem M., 2020) 


\subsection{The Data Used}

We used data from presidential elections and other population data. The electoral data are taken from the website of the IHAE (www.isie.tn), while those of the population are taken from the General Census of Population and Habitat (GCPH) published by the National Institute of Statistics (NIS) in 2014 (www.ins.nat.tn).

\subsection{Methodology and Software Used}

In this work, we have used open source software. We developed the base maps using the Phildigit software (http://philcarto.free.fr/InstalPhildigit.html). We used Philcarto to produce thematic maps (http://philcarto.free.fr/InstalPhilcarto5.5.html). Both are "freely downloadable on the Internet and used in many countries for teaching and research" (http://philcarto.free.fr/CVDoc/waniez_cv.pdf). The French geographer Philippe Waniez is the author of these two programs. For the layout and wrapping of the maps, we have used the free software Inkscape downloadable from the website: https://inkscape.org/release/inkscape-0.92.4/. The data tables are entered and organized on the Excel software.

Using this software, we produced several maps of different types. A «nominal» map, to represent the electoral division (figure 2), other choropleth maps to show the ratios and other proportional symbols maps, to represent the stocks. On some choropleth maps, we added graphs that represent the spatial autocorrelation between the spatial units concerning the mapped variable. Small tables are inserted on these last maps. In these tables, we have represented the values of the spatial autocorrelation of Moran and Geary (Daniel A and Griffith, 2016; Piffer, D. 2015; Gelade, G. A. 2008; Gordon, R. A., 2015; https://en.wikipedia.org/; Emil O. W. Kirkegaard, 2015).

The Moran coefficient measures spatial autocorrelation between spatial data. It varies between -1 and +1 . "Positive values mean positive spatial autocorrelation, while negative values mean negative spatial autocorrelation" (https://en.wikipedia.org/). If the index is equal to -1 , it is a total dispersion (Figure 5-c), if it is equal to 1, it is a total grouping of spatial units (Figure 5-a). If its value is of the order of 0 , it is a total independence, that is to say that there is no spatial autocorrelation and the distribution is therefore random (figure 5-b). This coefficient "verifies whether an object is similar to other objects that surround it or not, and whether the objects have attracted or repelled" (https://www.statisticshowto.datasciencecentral.com/). The Moran index is written as follows (Figure 3):

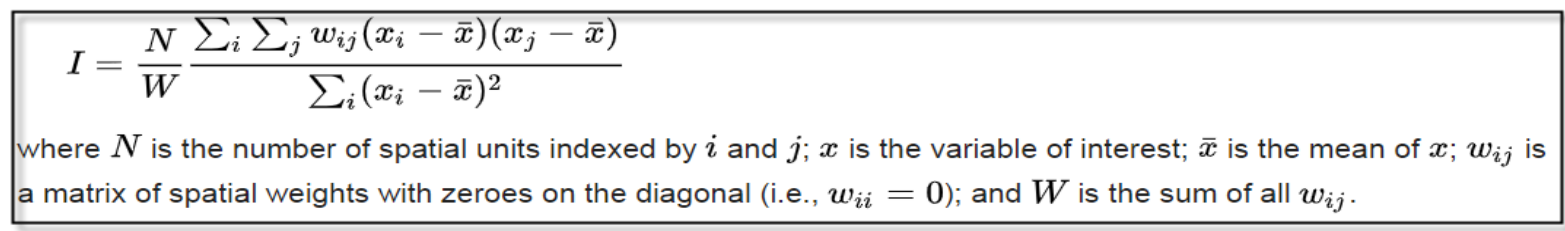

Figure 3. Moran coefficient. (Source: https://fr.wikipedia.org/).

The second coefficient we that used for measuring spatial autocorrelation is that of Geary. It is written as follows (Figure 4):

$$
C=\frac{(N-1) \sum_{i} \sum_{j} w_{i j}\left(x_{i}-x_{j}\right)^{2}}{2 W \sum_{i}\left(x_{i}-\bar{x}\right)^{2}}
$$

where $N$ is the number of spatial units indexed by $i$ and $j ; x$ is the variable of interest; $\bar{x}$ is the mean of $x$; $w_{i j}$ is a matrix of spatial weights with zeroes on the diagonal (i.e., $w_{i i}=0$ ); and $W$ is the sum of all $w_{i j}$.

Figure4. Geary coefficient. (Source: https://fr.wikipedia.org/).

"The values of the Geary coefficient vary between 0 and an unspecified value greater than 1 . Values less than 1 mean increasing positive au-correlations. Values greater than 1 , on the other hand, mean decreasing negative spatial auto-correlations" (https://en.wikipedia.org/).

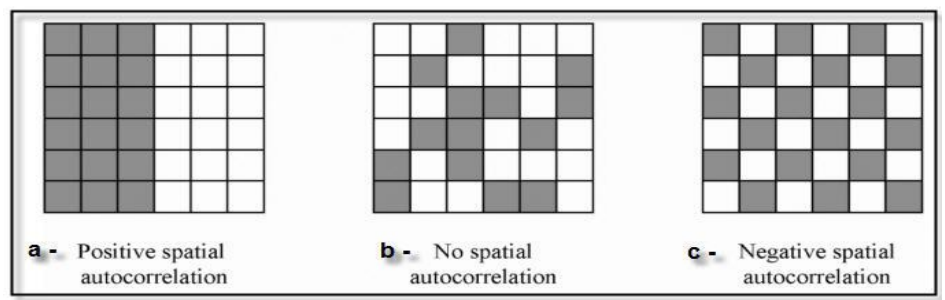

Figure5. "Illustrations of spatial auto-correlation" (Source: Emil O. W. Kirkegaard, 2015) 
The graphs, presented in some maps (Figure $6 ; 8 ; 12 ; 14$ and 16), show whether there is a spatial autocorrelation between the different constituencies or not. If the segment connecting two electoral constituencies is thick, it means that the spatial auto-correlation is strong. If, on the other hand, the line is thin, the auto-correlation is low. The absence of segments between electoral constituencies means the absence of spatial auto-correlation.

\section{MAPPING AND ANALYSIS OF ELECTION RESUltS}

We analyze the results through voter turnout, the votes declared obtained by each candidate, the blank and the rejected ballots.

\subsection{Participation Rate}

The national rate of participation in the elections is $39.2 \%$. It varies between $31.1 \%$ in Baja and $51.1 \%$ in Kasserine. The classification of the constituencies into six classes according to the Jenks method (Figure 6) shows that after Kasserine, which is alone in the first class, we meet Kebilli and Ben Arous in the second class. Subsequently, we find respectively Tunis 2, Sfax 2, Sousse, Ariana and Nabeul1. The fourth class consists of eight electoral constituencies with participation rates ranging from $38.6 \%$ to $40.9 \%$. The fifth class includes 6 electoral constituencies with rates varying between 36 and $37.9 \%$. Finally, the last set is made up of 4 constituencies, with values between $30.1 \%$ and 33 .

In figure 6, the thick segments show strong spatial auto-correlations between several copula or triples of constituencies such as Gafsa-Tozeur-Gabès, Siliana-Kef-Zagwène, Mannouba-Bizerte and Medenine-Tataouine. Average spatial auto-correlations are expressed by thin segments; this is the case of the Sousse-Monastir-Mahdia-Sfax1-Sfax2-Kairouen, Baja-Siliana-Kairouen-Mahdia and Mannouba-Zaghwène-Kairouen sets.

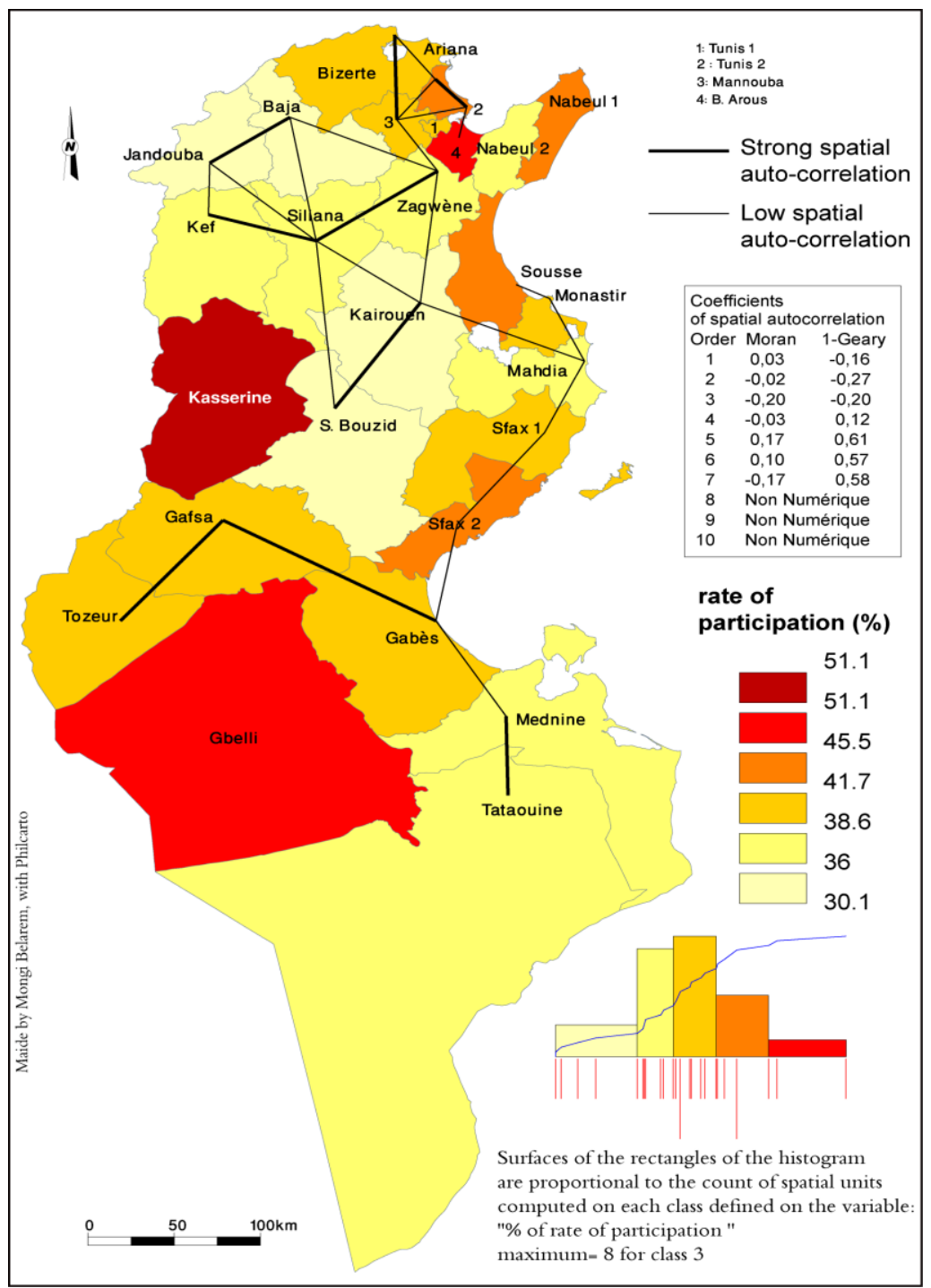

Figure6. Rate of participation in the second round of Tunisia's 2019 presidential elections by constituencies. 


\subsection{All Votes Cast}

We designate by all the votes, the sum of the valid votes, the white votes and the rejected votes. The total number of votes within the country is 3797739 . The largest number of votes is recorded in the constituency of Ben Arous (237070). On the other hand, the smallest number is recorded in Tozeur (42958). In each of the five constituencies of Ben Arous, Sousse, Sfax 2, Monastir and Tunis 2, the number of votes exceeds 200000. Whereas in each of the constituencies of Tozeur, Tataouine, Zaghouan, Siliana, Kebili, Kef and Beja, the number of votes does not exceed 100000 (Figure 7).

\subsection{Valid Votes}

Valid votes "are also called declared votes or cast votes. These are votes that are neither null nor white" (Belarem M., 2020). They account for 3727935 and represent $98.18 \%$ of the total votes. Their number varies between 232778 in Ben Arous and 42407 in Tozeur. Their shares of the total votes are generally strong in all constituencies. They vary between $98.97 \%$ in Gbelli and $97.06 \%$ in Kef. In each of the constituencies of Ben Arous, Sousse, Sfax 2 and Monastir, the number of valid votes exceeds 20000, while in each of the constituencies of Baja, Kef, Gbèlli, Siliana, Zagwène, Tataouine and Tozeur, they are less than 10000 (Figure 8 and 9). In Figure 8, we find that the percentages of valid votes for all votes are strong. They define a gradient decreasing from the South to the North. The highest shares are recorded in the southern electoral constituencies. Moving towards the North (and especially towards the North West), the percentages decrease slightly. In Figure 8, which represents the percentages of valid votes of all votes, the graph of spatial auto-correlations shows that the two constituencies of Sfax and Sidi Bouzid (belonging to the Centre of the country) are strongly correlated with some other southern electoral constituencies (Gabès, Gafsa, Tozeur, Gbèlli, Mednine and Tataouine). The constituencies of Mahdia, Sousse, Monastir (from the East Centre) also have strong spatial auto-correlations with the northern constituencies of Siliana, Zagwène, Nabeu1 and Ben Arous. Some other constituencies such as Baja, Jendouba and Kef in the North West have weak spatial auto-correlations with the constituencies of and Kassenine, Gafsa, Sidi Bouzid belonging to the Center and with other constituencies belonging to the South West on the other hand.

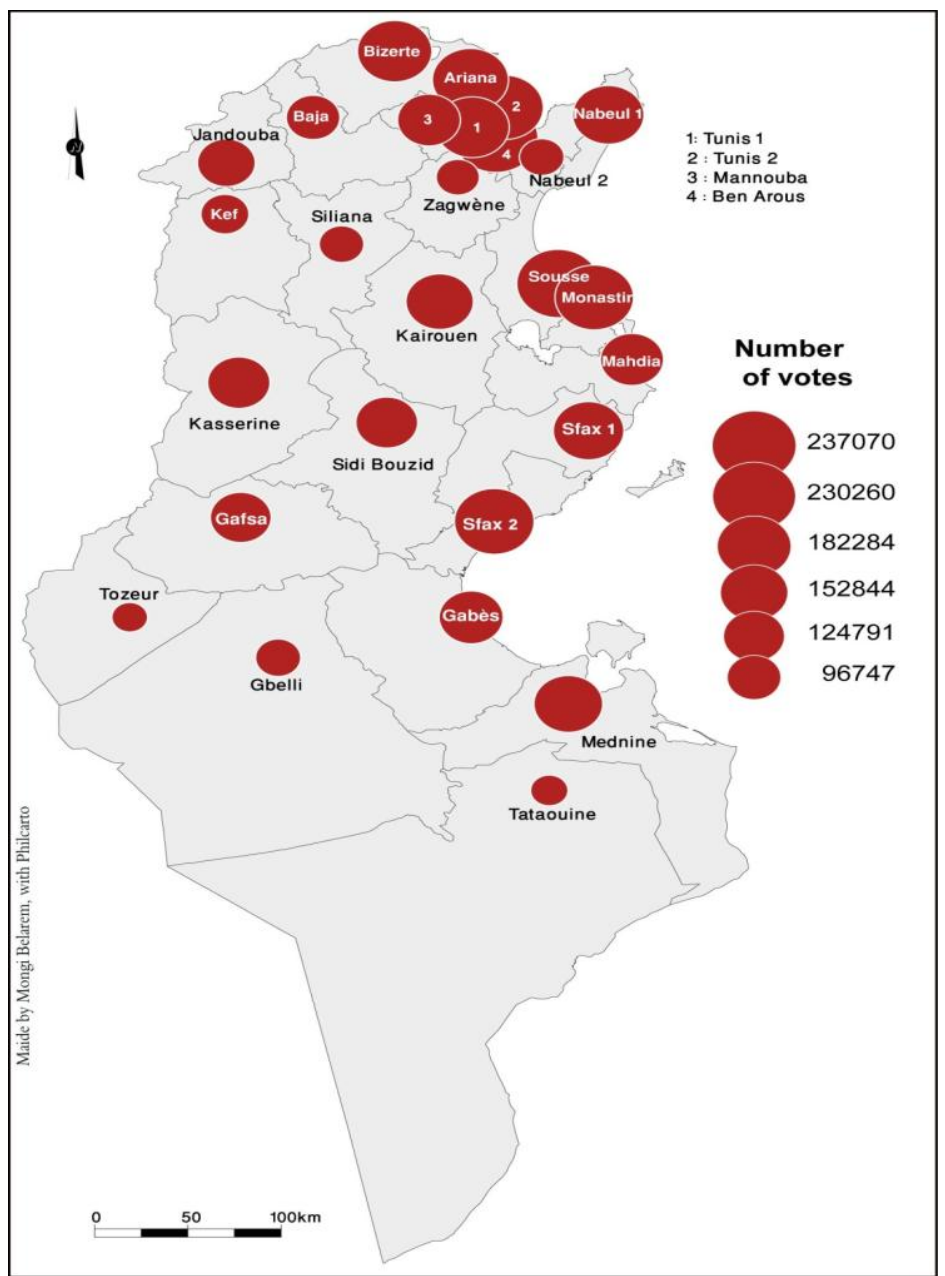

Figure7. Number of votes in the second round of Tunisia's 2019 presidential elections by constituencies. 


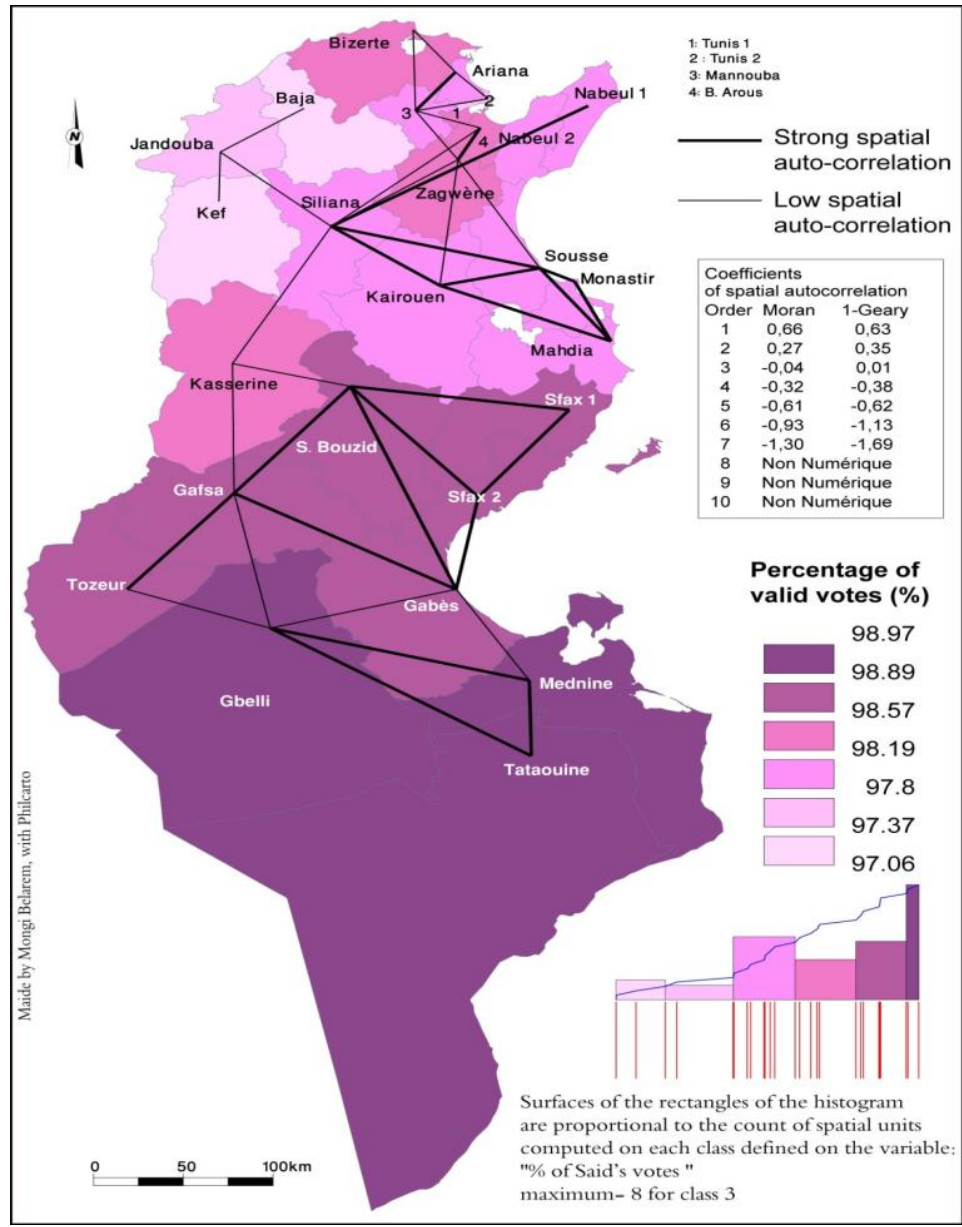

Figure8. Percentage of valid votes in the second round of Tunisia's 2019 presidential elections by constituencies.

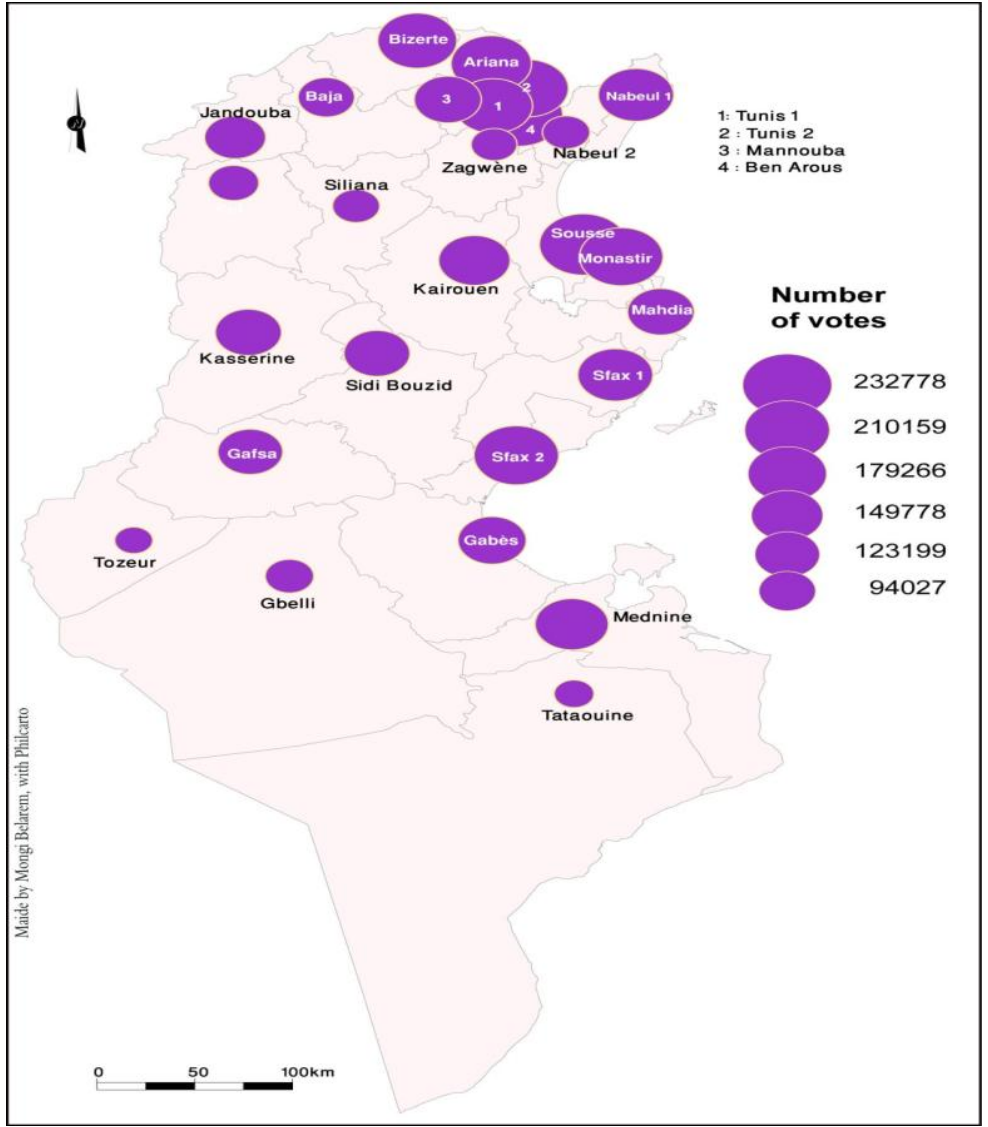

Figure9. Number of valid votes by constituencies in the second round of Tunisia's 2019 presidential elections. 


\subsection{The Results Obtained by Each Candidate}

Both candidates entered the second round after competing with 24 other candidates (Figure 10). During the first round, K. Saïed obtained $18.4 \%$, N. Karoui gained $15.58 \%$ of the total votes. In the second round, K. Saïed won with $72.71 \%$ of the total votes, his opponent got only $27.29 \%$ (Figure 11 ) (www.isie.tn).

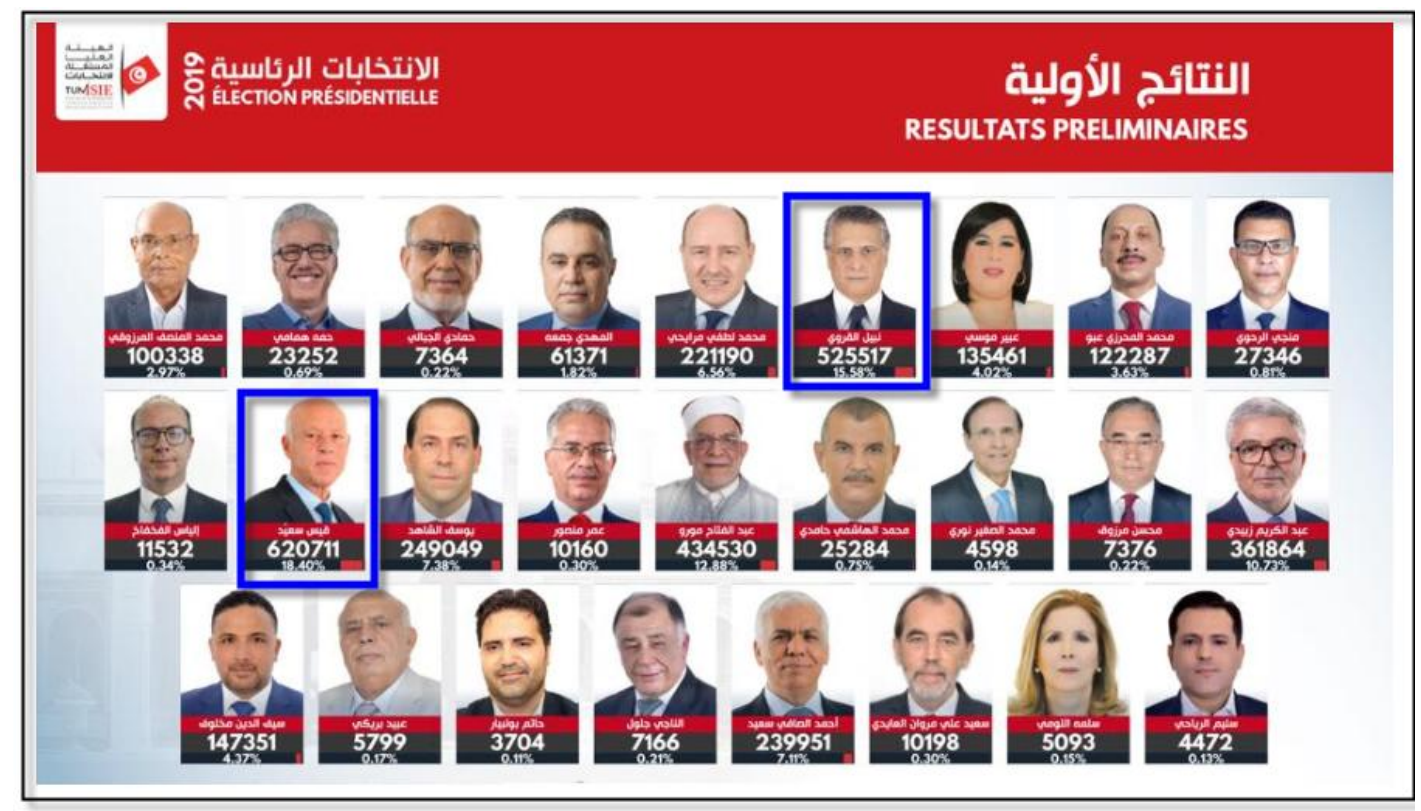

Figure10. Results of the first tour (K. Saïed and N. Karoui in blue) (Source: Journal Bab Bnet, 2019).

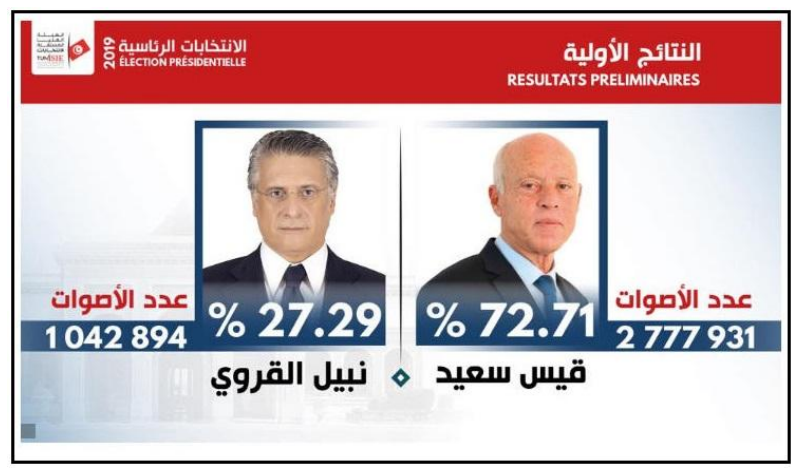

Figure11. Results of the second tour and the victory of K. Saïed (Source: Journal Bab Bnet, 2019).

\subsubsection{Results Obtained by Kaïs Saïed.}

Originally from the governorate of Nabeul (North-East of the country), K. Saïed was born in 1958. He is a retired university specialist in constitutional law. He was "Secretary General of the Tunisian Association of Constitutional Law from 1990 to 1995, and then Vice-president of the Association since 1995". «He taught constitutional law at the Faculty of Law of Sousse (Centre Est du pays) from 1994 until 1999, then at the Faculty of Legal and Political Sciences of Tunis between 1999 and 2018». «He was President of the Tunisian Association of Constitutional Law from 1995 to 2019» (Mlika Amina, 2019).

He became president after obtaining 2777931 votes ( $72.71 \%$ of all votes), with 2706191 votes inside the country $(72.59 \%)$ and 71740 votes abroad $(77.23 \%)$. He won in all electoral constituencies. The number of votes obtained by this candidate varied between 35367 in Tozeur and 174142 in Ben Arous. It exceeded 150000 votes in each of the three constituencies of Ben Arous, Sfax 2 and Sousse. He did not exceed 50000 votes in each of the three constituencies of Tozeur, Siliana, El Kef, Zaghwène and Tataouine (Figure 12 and figure 13).

The proportions obtained by K. Saïed vary between $56.44 \%$ in El Kef and $96.09 \%$ in Tataouine. He exceeded the national average (72.71\%), in 11 constituencies (Tataouine, Médenine, Gabès, Tozeur, Sfax 1 and 2, Gafsa, Ben Arous, Mannouba, Tunis 1 and Nabeul 2). 
Figure 12 shows, on the one hand, a strong spatial auto-correlation between the southern constituencies (Tataouine, Médenine, Gabès and Kébilli) in which K. Saïed exceeded $90 \%$ of the total votes. Gafsa is also strongly correlated with Tozeur. On the other hand, a strong spatial autocorrelation is observed in the constituencies of Mannouba, Nabeul 1 and Zaghwène (Centre Est) and those of Sousse, Monastir, Mahdia and Kairouen (North East). In the West Central and North West electoral constituencies, K. Saied had the lowest results. These latter constituencies are moderately auto-correlated with each other.

Figure 16, which shows the percentage differences between the two candidates, is almost identical to Figure 12. In Figure 16, we have represented the result of the subtraction of the proportions obtained by K. Saïed by the proportions obtained by N. Karoui. (\% of votes of Saïed - \% of votes of Karoui). This figure illustrates that all the constituencies in the country voted for Saïed and especially those in the South. Generally, the people who voted for K. Saïed, opted to vote against the system that governed for decades, and against the political parties that governed after the 2011 revolution, without having succeeded in overcoming the country's socio-economic crisis (Ben Fguira S. and Belarem, M. 2018; Chouari W. and Belarem M. , 2016; Franklin M., 1992a and al.; Franklin M.,1992b; Gana Al., 2011; Gana A. and al 2012; Gana Al., 2016 and al.). The majority of those who voted for K. Saïed are young (Blaise L. 2019); nine out of ten young people voted for this candidate

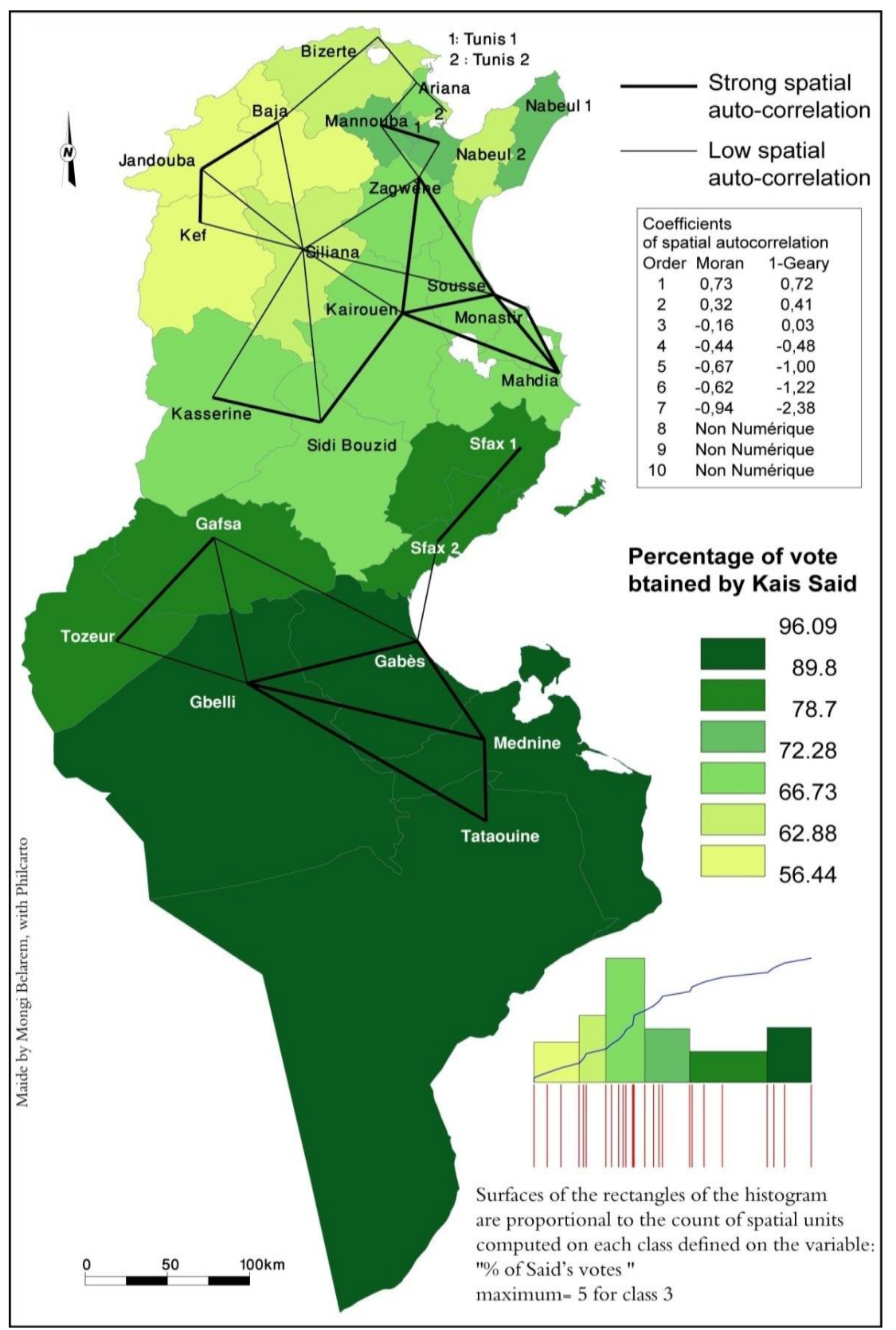

Figure12. Percentage of vote obtained by Kaïs Saïed in the second round of Tunisia's 2019 presidential elections by constituencies. 


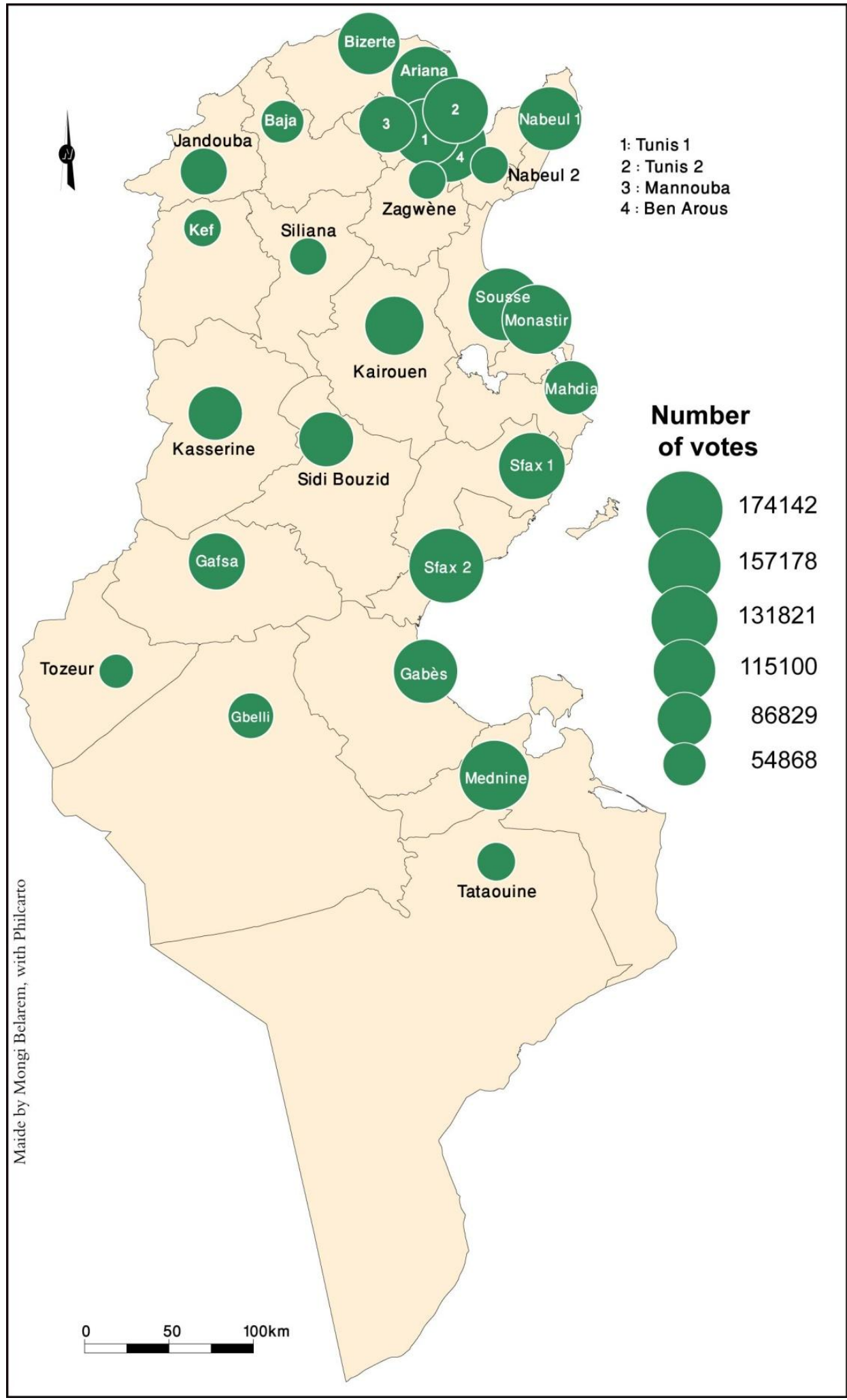

Figure13. Number of votes obtained by Kaïs Saïed in the second round of Tunisia's 2019 presidential elections by constituencies.

\subsubsection{The Results Obtained by Nabil Karoui.}

The candidate N. Karoui is a businessman, born in 1963 in Bizerte. He is one of the great actors in the field of advertising in Tunisia. He is a shareholder in the "Nesma Tv" chain (https://www.nessma.tv), with his brother Ghazi, with $25 \%$ of the value of the channel. Nesma Tv broadcasts political and social programs for the benefit of this candidate. He also benefited politically from the activities of the social association "Khalil Tounis" which established it in recent years (http://www.khaliltounes.com). This social association distributes aid to disadvantaged areas. 
During the second round of the elections, N. Karoui obtained 1042894 votes, which represents $27.29 \%$ of all votes. Abroad, he had 21150 votes $(22.77 \%$ of the votes from abroad). Within the country, he acquired 1021744 votes $(27.41 \%$ of the votes of the interior). The largest number of votes he obtained is recorded in Tunis 2 (72621 votes), the lowest is recorded in Tataouine (1809 votes). The largest share of all votes, acquired by this candidate, is recorded in El Kef (43.55\%). He therefore did not win in any constituency. The lowest share is in Tataouine (3.9\%) (Figure 14 and figure 15).

Generally the largest shares of this candidate are registered in the North West, and especially in the constituencies of Baja, Jandouba and El Kef which are spatially correlated between them strongly. On the other hand, the lowest percentages are recorded in the South and especially in the constituencies of Gabès, Medenie, Gbelli and Tataouine, which are characterised by a strong spatial auto-correlation (Figure 14). The highest proportions, obtained by N. Karoui in the constituencies of the North West, are partly explained by the activities of the association «Khalil Tounis» which distributed aid for the weakest social strata in this region. «Detained by the authorities for almost seven weeks in a case of tax evasion and money laundering, Karoui is released before two days of the $2^{\text {nd }}$ round by the Court of Cassation » (Bobin F., 2019 and Bobin F. and al, 2019). During this period of arrest, the other candidate K. Said refused to run his election campaign in sympathy with his competitor.

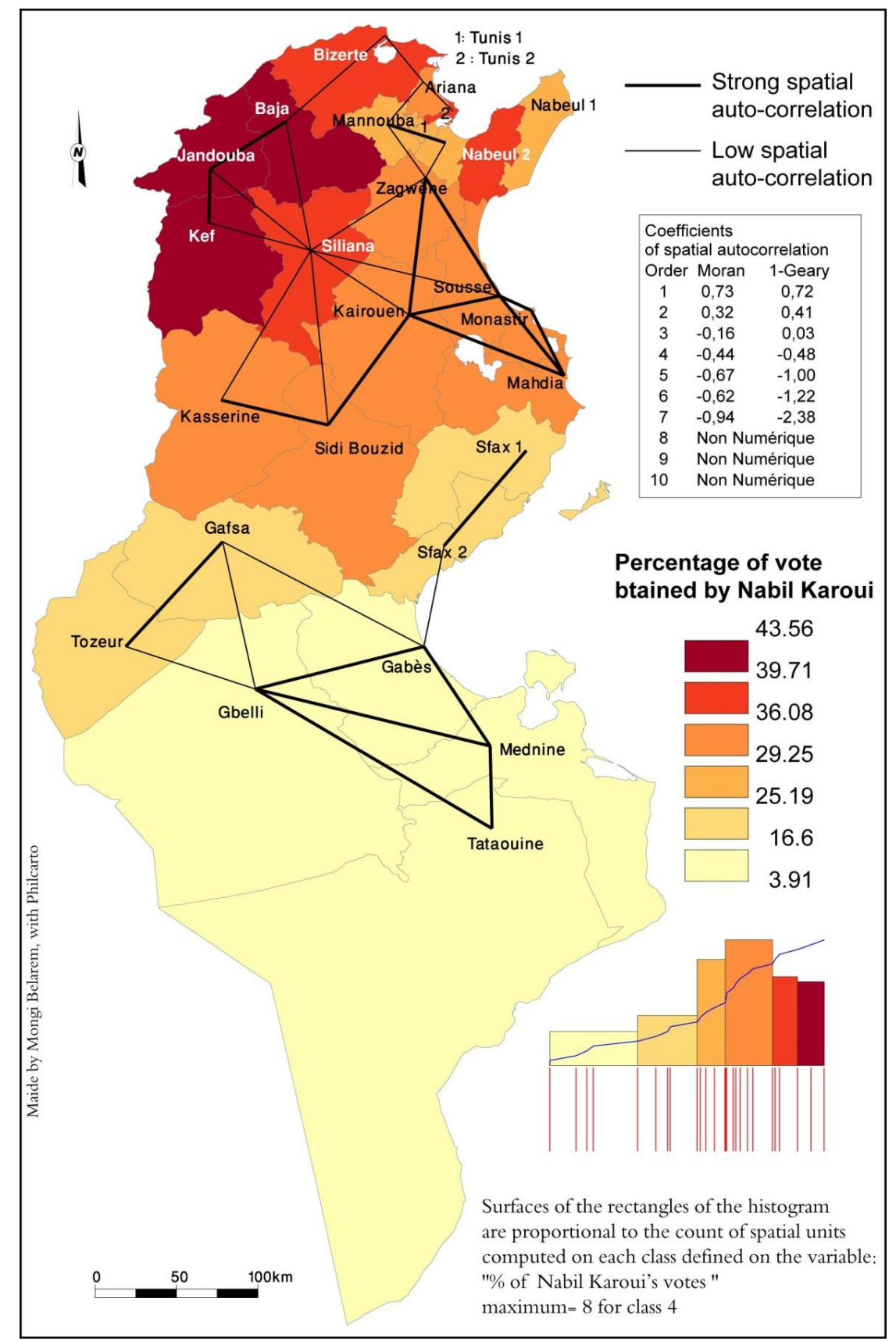

Figure14. Percentage of vote obtained by Nabil Karoui in the second round of Tunisia's 2019 presidential elections by constituencies. 


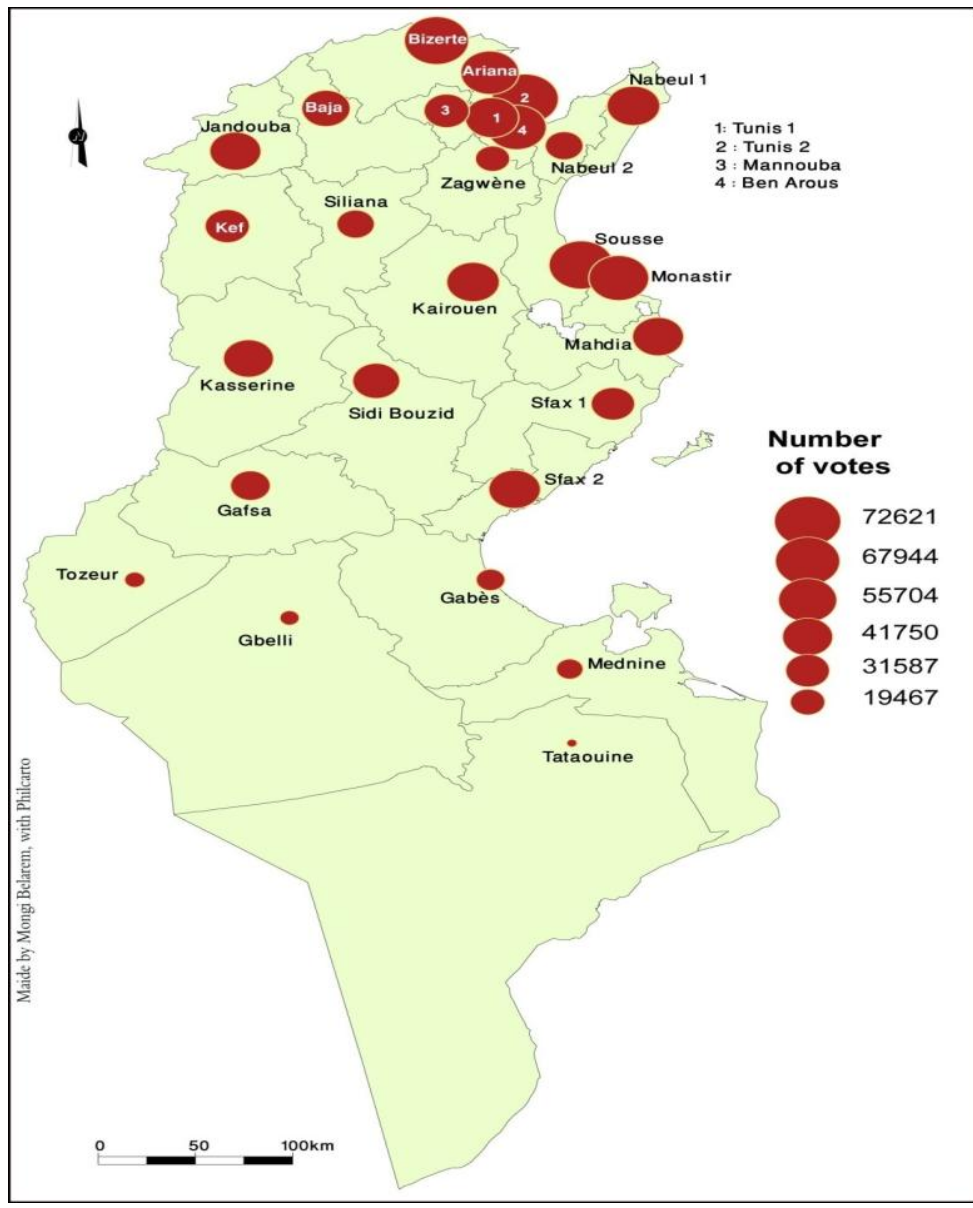

Figure15. Number of votes obtained by Nabil Karoui in the second round of Tunisia's 2019 presidential elections by constituencies.

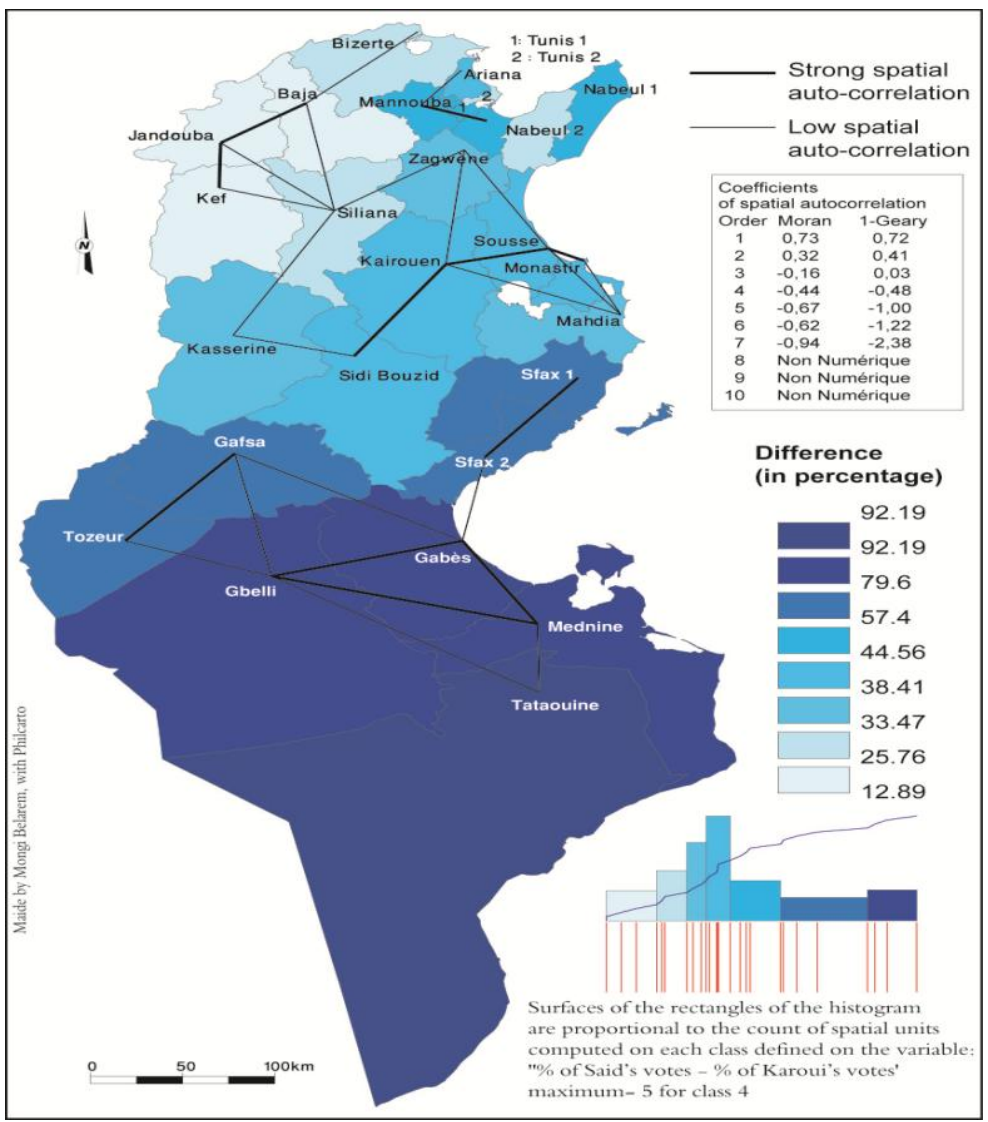

Figure16. Difference between the votes obtained by the two candidates (in percentage) by districts in Tunisia's 2019 presidential elections. 


\subsection{Invalid Votes}

Here we mean invalid votes, blank and rejected ballots (null). In many democracies, especially in the West, the two types of ballots (blank and spoiled) « are counted together and no statistics are provided on either side» (Geoffrey Pion, 2010). In Tunisia, each type is counted alone; statistics on both types are therefore provided separately.

\subsubsection{Blank Ballots}

The white ballot is "any ballot containing no signs of any kind" (http://www.legislation.tn/; Bercé Yves-Mariec, 1969). It is "a ballot put in the ballot box on which there is no name or mention" (Larousse, 1982). According to Geoffrey Pion, "the white vote refers to blank ballots of all registrations" (Geoffrey Pion, 2010).

Generally, the share of white ballots is low, in France it is around $4 \%$ on average, $2 \%$ in Germany and $0.5 \%$ in the Netherlands (Geoffrey Pion, 2010). The total number of white ballots registered within the country is 16954 . Their proportion is relatively negligible. It represents $0.43 \%$ of all votes. The largest number of white ballots is recorded in the constituency of Tunis 1 (2356), while the smallest is recorded in Tozeur (137 ballots). In each of the 14 constituencies, the number of these ballots does not reach 500. Their share exceeds $1 \%$ only in the constituency of Tunis 1 . The smallest share is recorded in Gbelli (0.25\%). Except for the electoral constituency of Tunis 1, the proportion of blank ballots does not reach $0.7 \%$ in all other electoral constituencies (Figure 17).

According to Pascal Jan, «the white vote expresses the opinion of an elector who expresses his attachment to the election (contrary to the abstentionist) and who considers that the political offer does not allow him to make a choice, to lean for one candidate rather than another» (https://en.wikipedia.org)

Voting white is expressing a desire and a way of seeing things in a way that is different from what the candidates propose. It is also a way of rejecting candidates' policies.

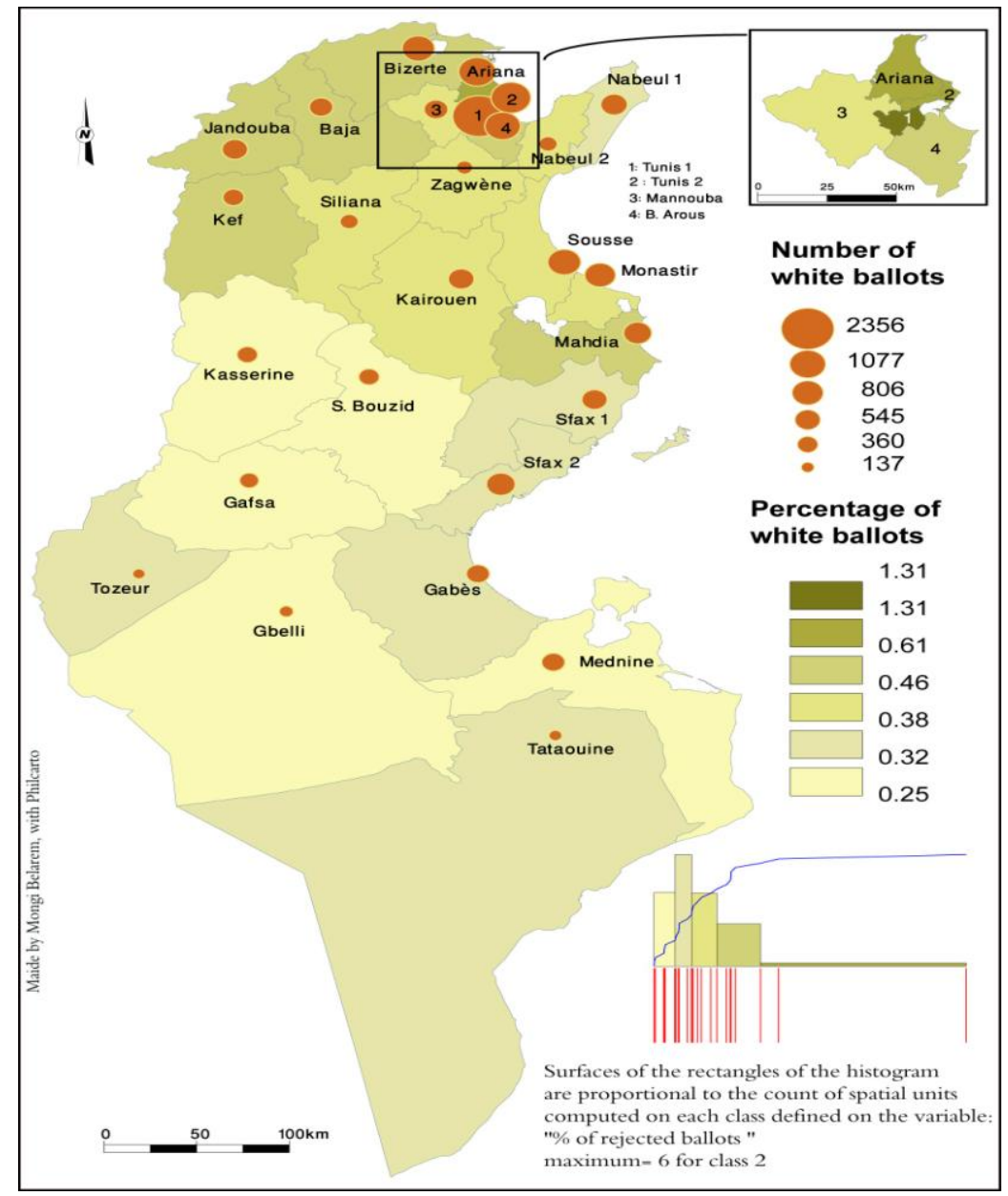

Figure17. Number and percentage of white ballots in the second round of Tunisia's 2019 presidential elections by constituencies. 


\subsubsection{Rejected Ballots}

According to Geoffrey Pion, the null ballots are those contrary to the electoral rule, therefore cancelled. It may in this case be a scorecard, torn, filled with an inappropriate pen. They may be the result of a will of the elector or a vote error" (Geoffrey Pion, 2010).

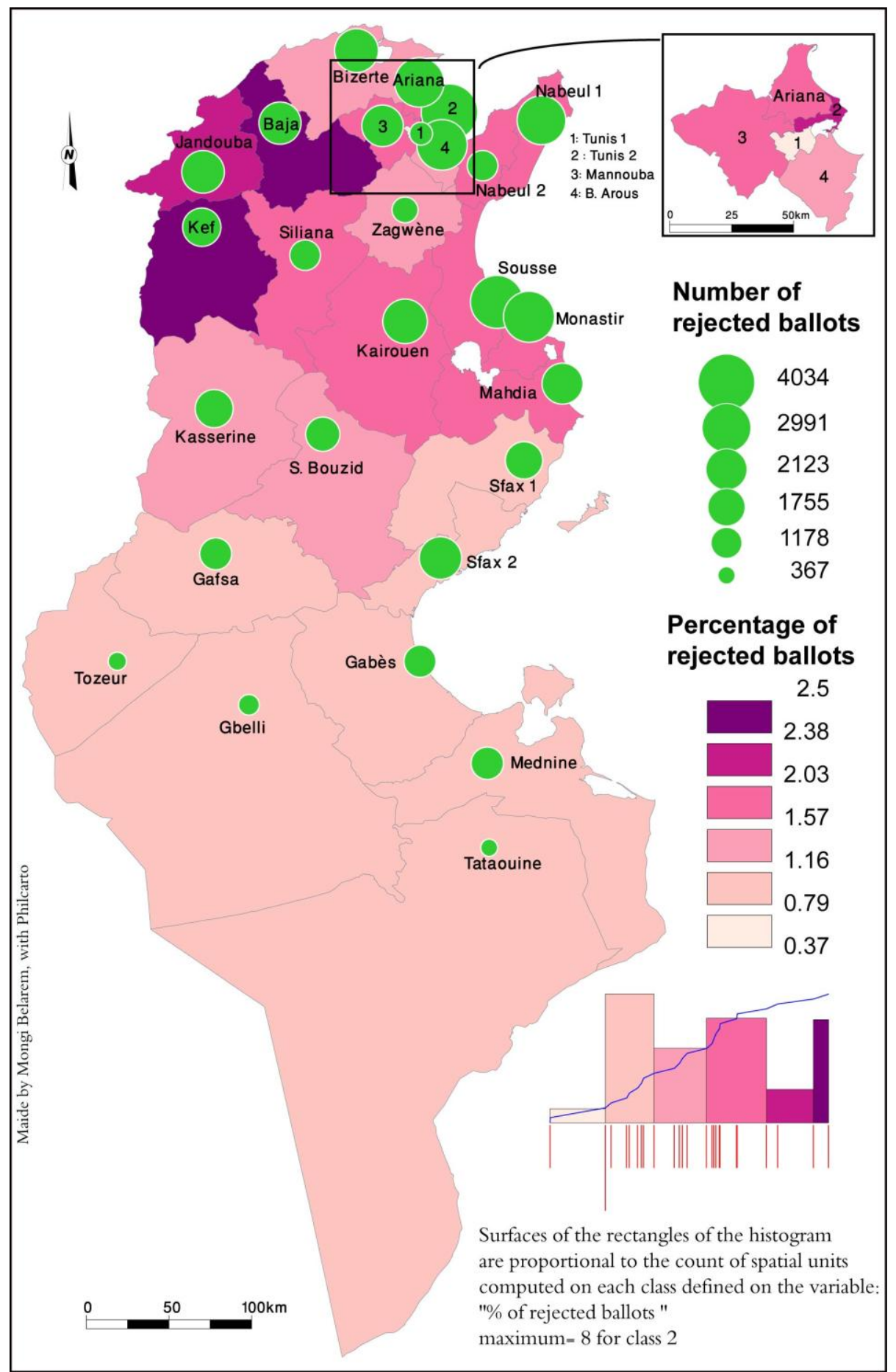

Figure18. Number and percentage of rejected ballots in the second round of Tunisia's 2019 presidential elections by constituencies.

The total number of rejected ballots registered within the country is 52580. Their proportion is relatively negligible, representing $1.41 \%$ of all votes (Figure 18). The largest number of rejected ballots is registered in Tunis 2 (4034), while the smallest is registered in Tataouine (367 ballots). In each of the four constituencies of Tataouine, Gbelli, Tunis 1 and Zagwène, the number of these ballots does not reach 1000. The proportion of rejected ballots in all ballots is $1.4 \%$. It only exceeds $1 \%$ in 6 electoral constituencies (Figure 18). The smallest proportion is recorded at Gbelli $(0.25 \%)$. While the highest proportion is recorded at El Kef (2.5\%) (figure 18). 


\section{CONCLUSION}

Based on this study, we find that mapping is a very effective tool for visualizing and analyzing electoral data. It has allowed us to show spatial inequalities of the results. In the first place, we analysed the spatial distribution of all the votes and the participation rates in the second round of the Tunisian presidential elections. Then we mapped and analyzed the results of each candidate, which showed K. Said's victory in all the constituencies. Finally, we analyzed the spatial distribution of invalid bulletins.

This mapping approach that we have followed can be applied to other electoral variables to visualize other faces of elections.

\section{REFERENCES}

[1] Belarem Mongi. (2019).Cartographie des élections municipales tunisiennes de 2018 à l'échelle macroscopique : l'exemple de la circonscription de Sfax 2. International Journal of Humanities and Cultural Studies (IJHCS)ISSN 2356-5926. Vol 6, No 3 (2019) https://www.ijhcs.com/index.php/ ijhcs/article/view/3376/3119.

[2] Belarem Mongi. (2020). Multi-Scalar Mapping of Potential Voters in Tunisia's 2019 Presidential Elections. Open Journal of Political Science, 10, 27-40. https://doi.org/10.4236/ojps.2020.101.

[3] Benoit Le Rubrus (2011). Cartographie et analyse territoriale multiscalaire. Réingénierie des logiciels HyperAtlas et Hyper Admin. Vision par ordinateur et reconnaissance de formes [cs.CV]. 2011.

[4] Bercé Yves-Mariec (1969). Les bulletins nuls, source de la microsociologie électorale. In: La Gazette des archives, ${ }^{\circ} 65$, 1969. pp. 75- 84; doi : https://doi.org/10.3406/gazar.1969.2070 https://www.persee.fr/ doc/gazar_0016-5522_1969_num_65_1_2070.

[5] Bobin Frédéric (2019). En Tunisie, la libération de Nabil Karoui relance la campagne présidentielle. Journal Le Monde, Par Publié le 09 octobre 2019 à $20 \mathrm{~h} 55$ - Mis à jour le 10 octobre 2019 à $10 \mathrm{~h} 42$

[6] Bobin Frédéric, Mohamed Haddad et Lilia Blaise (2019). «Elections en Tunisie : la relation ambivalente de Kaïs Saïed avec les parlementaires d'Ennahda». Journal Le Monde, Publié le 14 octobre 2019 à $11 \mathrm{~h} 33$ - Mis à jour le 16 octobre 2019: https://www.lemonde.fr/afrique/article/2019/10/16/presidentielle-entunisie-kais-saied-a-un-discours-qui-repond-a-la-jeunesse_6015731_3212.html.

[7] Chouari Walid et Belarem Mongi , (2016). «Enjeux de la Tunisie orientale : un territoire développé et un environnement à protéger », Confins [En ligne], 30|2017, mis en ligne le 18 février 2017, consulté le 11 novembre 2019. URL: http://journals.openedition.org/confins/11701 ; DOI : 10.4000/confins.11701.

[8] Daniel A. Griffith (2016). "Spatial autocorrelation and Art», Cybergeo : European Journal of Geography [En ligne], Les 20 ans de Cybergeo, mis en ligne le 22 janvier 2016, consulté le 26 novembre 2019. URL : http://journals.openedition.org/cybergeo/27429

[9] Dhieb Mohsen et Belarem Mongi (2016). « Le découpage administratif tunisien : Entre enjeux politique et administratif et représentation citoyenne », in Colloque International: Maillages territoriaux, Démocratie et Élection, pp 30-38. http://riate.cnrs.fr/wp-content/uploads/2017/01/Actes-de-conf\%C3\%A9rence_Mona stir 2016_VF_090117.pdf

[10] Emil O. W. Kirkegaard, (2015). Some methods for measuring and correcting for spatial autocorrelation. https://thewinnower.com/papers/2847-some-methods-for-measuring-and-correcting-for-spatialautocorrelation

[11] Franklin M., 1992b, The decline of cleavage politics, in Franklin M., Mackie T., Valen H., Electoral change: response to evolving social and attitudinal structure in western countries, Cambridge, Cambridge University press, pp383-405

[12] Franklin M., Mackie T., Valen H., 1992a, Electoral change: response to evolving social and attitudinal structure in western countries, Cambridge, Cambridge University Press.

[13] Gana Alia \& Van Hamme, Gilles, Élections et territoires en Tunisie, (2016). Enseignements des scrutins post-révolution (2011-2014), Karthala, 2016.

[14] Gana Alia, 2011, Les inégalités socio-territoriales aux origines de la révolution tunisienne : Défis du développement, enjeux pour la recherche, Lettre de L'IRMC, Bulletin trimestriel n ${ }^{\circ} 6$ avril-août 2011 19-20

[15] Gana Alia, Gilles Van Hamme et Maher Ben Rebah, (2012). «Géographie électorale et disparités socioterritoriales: les enseignements des élections pour l'assemblée constituante en Tunisie », L'Espace Politique [En ligne], 18 |2012-3, mis en ligne le 21 décembre 2012, consulté le 24 octobre 2019. URL : http://journals.openedition.org/espacepolitique/2486 ; DOI : 10.4000/espacepolitique.2486

[16] Gelade, G. A. (2008). The geography of IQ. Intelligence, 36(6), 495-501. doi.org/10.1016/jintell.2008.01 .004 
[17] Geoffrey Pion, (2010). «Le vote blanc et nul en Wallonie: analyse écologique et individuelle », Belgeo [En ligne], 3 |2010, mis en ligne le 15 décembre 2012, consulté le 21 novembre 2019. URL : http://journals.openedition.org/belgeo/6441 ; DOI : 10.4000/belgeo.6441

[18] Gordon, R. A. (2015). Regression analysis for the social sciences (Second edition). New York: Routledge, Taylor \& Francis Group.

[19] Grand dictionnaire encyclopédique Larousse, 1982

[20] http://philcarto.free.fr/CVDoc/waniez_cv.pdf

[21] http://philcarto.free.fr/InstalPhilcarto5.5.html

[22] http://philcarto.free.fr/InstalPhildigit.html

[23] http://www.khaliltounes.com

[24] http://www.legislation.tn/

[25] https://d-maps.com/

[26] https://en.wikipedia.org

[27] https://fr.wikipedia.org/

[28] https://inkscape.org/release/inkscape-0.92.4/

[29] https://www.nessma.tv

[30] https://www.statisticshowto.datasciencecentral.com/

[31] Journal Bab Bnet, 14 octobre 2019 ; https://www.babnet.net/rttdetail-190899.asp).

[32] Lilia Blaise (2019), «Présidentielle en Tunisie : Kaïs Saïed a un discours qui répond à la jeunesse ». Journal Le Monde, publié le 16 octobre 2019 à $13 \mathrm{~h} 00$ - Mis à jour le 16 octobre 2019 ; https://www.lemonde.fr/afrique/article/2019/10/16/presidentielle-en-tunisie-kais-saied-a-un-discours-quirepond-a-la-jeunesse_6015731_3212.html

[33] Mlika Amina (2019). Journal 1'Actualité Kapitalis : consulté le 29/11/2019; http:// kapitalis.com/tunisie /2019/09/03/biographie-de-kais-saied-candidat-aux-presidentielles-anticipees-du-15-septembre/; https://fr.wikipedia.org/).

[34] Mongi Belarem (2017). Cartographie multi scalaire des élections tunisiennes de 2011. In revue du CERES N³ - Série Cartographie, pp91, 106. Tunis. ISBN 978-9973-902-54-

[35] Piffer, D. (2015). A review of intelligence GWAS hits: Their relationship to country IQ and the issue of spatial autocorrelation. Intelligence, 53, 43-50. doi.org/10.1016/j.intell.2015.08.008

[36] Sami Ben Fguira et Mongi Belarem, (2018). «Quel avenir pour le logement social en Tunisie? », Confins [En ligne], 36 | 2018, mis en ligne le 30 juin 2018, consulté le 10 octobre 2019. URL : http://journals.openedition.org/confins/13450 ; DOI : 10.4000/confins. 13450

[37] www.ins.nat.tn

[38] www.isie.tn

Citation: Mongi Belarem. "Mapping of the Results of the Second Round of Tunisia's 2019 Presidential Elections" International Journal of Political Science (IJPS), vol 6, no.1, 2020, pp. 7-21. doi: http://dx.doi.org/10. 20431/2454-9452.0601002.

Copyright: (C) 2020 Authors. This is an open-access article distributed under the terms of the Creative Commons Attribution License, which permits unrestricted use, distribution, and reproduction in any medium, provided the original author and source are credited. 